\title{
In situ assessment of genotoxicity in tadpoles (Amphibia: Anura) in impacted and protected areas of Chapada Diamantina, Brazil
}

Avaliação in situ da genotoxicidade em girinos (Amphibia: Anura) em áreas impactadas e protegidas na Chapada Diamantina, Brasil

\author{
M. B. Silva ${ }^{1 *}$; R. E. Fraga ${ }^{1}$; P. B. Nishiyama ${ }^{1}$; N. L. B. Costa ${ }^{1}$ I. S. S. Silva ${ }^{1}$; D. \\ A. Brandão ${ }^{1}$; T. S. Queiroz ${ }^{1}$; M. A. Rocha ${ }^{1}$; F. A. Juncá ${ }^{2}$ \\ ${ }^{1}$ Laboratório de Zoologia, Universidade Federal da Bahia, Campus Anísio Teixeira, Instituto Multidisciplinar em \\ Saúde, 45029-094, Vitória da Conquista-Bahia, Brasil \\ ${ }^{2}$ Museu de Zoologia, Universidade Estadual de Feira de Santana, Departamento de Ciências Biológicas, Museu de \\ Zoologia, 44036-900, Feira de Santana-Bahia, Brasil
}

*biolmarcioborba@gmail.com

(Recebido em 19 de outubro de 2020; aceito em 07 de fevereiro de 2021)

\begin{abstract}
We evaluated the genotoxic potential of surface water bodies in an area impacted by agrochemicals, in the Ibicoara-Mucugê agropole, Bahia and those within protected areas in Chapada Diamantina, Bahia, Brazil, using the micronucleus test as a biomarker in tadpole species native neotropicals. Our hypothesis is that the closer to agricultural farms, the more affected by mutagenic and genotoxic substances will be the environment and resident organisms. The micronucleus frequencies were determined in tadpoles of 11 species collected in 11 surface water bodies in coffee, corn, vegetable, and pumpkin plantations, as well as in adjacent sites within a protection area. Tadpoles of seven species found in agricultural sites exhibited higher frequencies of micronuclei compared to the six species from the protected locations. The species Bokermannohyla oxente and Leptodactylus latrans collected in agricultural areas exhibited the highest frequencies of micronucleated erythrocytes compared to the populations from the protected areas $(\mathrm{p}<0.05)$. Our results indicate that compounds present in surface water bodies in agricultural areas of the Ibicoara-Mucugê farm have genotoxic effects on anurans, showing the stress responses caused by agricultural activities associated with the use of complex mixtures of pesticides. Thus, anurans are excellent sentinel species in environmental monitoring, previously indicating the effect of xenobiotics on the environment.
\end{abstract}

Keywords: Anura, biomonitoring, micronuclei

Avaliamos o potencial genotóxico de corpos d'água superficiais em uma área impactada por agroquímicos, no agropólo Ibicoara-Mucugê, Bahia e aqueles dentro de áreas protegidas na Chapada Diamantina, Bahia, Brasil, por meio do teste de micronúcleos como biomarcador em espécies de girinos neotropicais nativos. Nossa hipótese é que quanto mais perto das fazendas agrícolas, mais afetados por substâncias mutagênicas e genotóxicas serão o meio ambiente e os organismos residentes. As frequências de micronúcleos foram determinadas em girinos de 11 espécies coletadas em 11 corpos d'água superficiais em plantações de café, milho, hortaliças e abóbora, bem como em sítios adjacentes dentro de uma área de proteção. Os girinos de sete espécies encontradas em locais agrícolas exibiram altas frequências de micronúcleos em comparação com os girinos de seis espécies coletadas em locais protegidos. Girinos de Bokermannohyla oxente e Leptodactylus latrans coletados em áreas agrícolas exibiram maiores frequências de eritrócitos micronucleados quando comparados as populações coletadas nas áreas protegidas $(\mathrm{p}<0,05)$. Nossos resultados indicam que compostos presentes em corpos d'água superficiais em áreas agrícolas do agropólo Ibicoara-Mucugê possuem efeitos genotóxicos para os anuros evidenciando o estresse causado pelas atividades agrícolas associadas ao uso de misturas complexas de agrotóxicos. Assim, anuros são excelentes espécies sentinelas em monitoramento ambiental, indicando previamente o efeito de xenobióticos no ambiente.

Palavras-chave: Anura, biomonitoramento, micronúcleos

\section{INTRODUCTION}

Agricultural activities are one of the principal causes of environmental degradation, either by habitat fragmentation or by the utilization of agricultural chemicals that contaminate the soil, water, 
and local biota [1]. According to Schiesari and Grillitsch (2010) [2] and Moreira et al (2019) [3], Brazil is the world's largest consumer of pesticides, resulting in an enormous input of environmental contaminants to soil and surface and subterranean waters, generating chemical pollution that, by its magnitude and omnipresence, threatens all forms of biodiversity.

Many authors have reported significant decreases in amphibian populations in many parts of the world during the last thirty years $[4,5,6]$. Among the possible causes proposed to explain those declines, environmental pollution has emerged near the top of the list, especially among populations living near centers of agricultural production [6-10].

The morphophysiological, ecological, reproductive, and behavioral characteristics of amphibians have been found to be quite sensitive to environmental pollutants. Their skins are highly permeable and offer little resistance to the absorption of many substances, including contaminants that can increase their susceptibility to illnesses and predators, incapacitate their reproduction, or negatively impact biochemical functions, thus compromising their survival $[2,11]$.

Micronuclei are an important genotoxic biomarker, that can indicate irreversible genetic damage in amphibian populations. They are defined as fragments of chromosomes or whole chromosomes that have not been incorporated into the main nucleus in cells that actively divide from any tissue $[6,12]$. The examination of micronuclei represents one of the best in vivo investigative cytogenetic approaches in the field of toxicology [13], as it involves quantifying micronucleus frequencies as a measure of integrated responses to accumulated stress caused by exposure to complex mixtures of environmental contaminants [14].

Micronucleus quantification in erythrocytes has been used with various fish and amphibian species to monitor potentially genotoxic aquatic pollutants [15-21]. Numerous investigations examining amphibian species inhabiting environments contaminated by large quantities of pesticides and other chemical substances have been undertaken and evidenced the efficiency of monitoring that biomarker [12, 22-27].

The Chapada Diamantina highlands are situated in the central portion of Bahia State in northeastern Brazil, within the "caatinga" dryland domain. The region is mountainous, with elevations up to $2000 \mathrm{~m}$ a.s.l., and represents the northern portion of the Espinhaço Range that lies slightly inland from the Atlantic coast. The region is famous for its natural beauty and comprises several different ecosystems (dryland caatinga vegetation, neotropical savanna ["cerrado"], rock outcrops, gallery forests, etc.) [28] demonstrating high degrees of endemism. That region has experienced intense agricultural development, however, especially along the Ibicoara-Mucugê plateau, with extensive plantations of coffee, potatoes, rice, vegetables, tomatoes, corn, and others. The agricultural model developed in the region is large-scale and directed toward exportation, with intensive vegetation suppression and significant applications of agrochemicals (herbicides, fungicides, and pesticides) [29]. Therefore, we seek to evaluate the genotoxic potential of agribusiness activities by assessing micronuclei biomarkers' responses of native neotropical tadpoles species (Amphibia: Anura) at different surface water bodies from areas impacted by agrochemicals used in large-scale agriculture compared to preserved waters at the neighboring Chapada Diamantina National Park. Our hypothesis is that the closer the agricultural farms, the more affected by mutagenic and genotoxic substances will be the environment and resident organisms. Such results can contribute to the monitoring of the toxic effects of xenobiotics in contaminated areas, through these sentinel organisms since our data refer to the real conditions of contamination and reveal the consequences of these stressors in the local biological community.

\section{MATERIALS AND METHODS}

This study was conducted with the formal approval of Ethics Committee on the Use of Animals of the Universidade Estadual de Feira de Santana (CEUA-UEFS), under registry number 02/2012. Animal collection was authorized by the Ministério do Meio Ambiente do Brasil (ICMBio license No. 27305-1). Tadpoles were sampled between November 2012 and February 2013 (corresponding to the rainy period) in six surface water bodies presumably contaminated by agro-defensive chemicals, and in five sites not subjected to that chemical input in the Chapada Diamantina National Park, Bahia State, Brazil (Figure 1). 

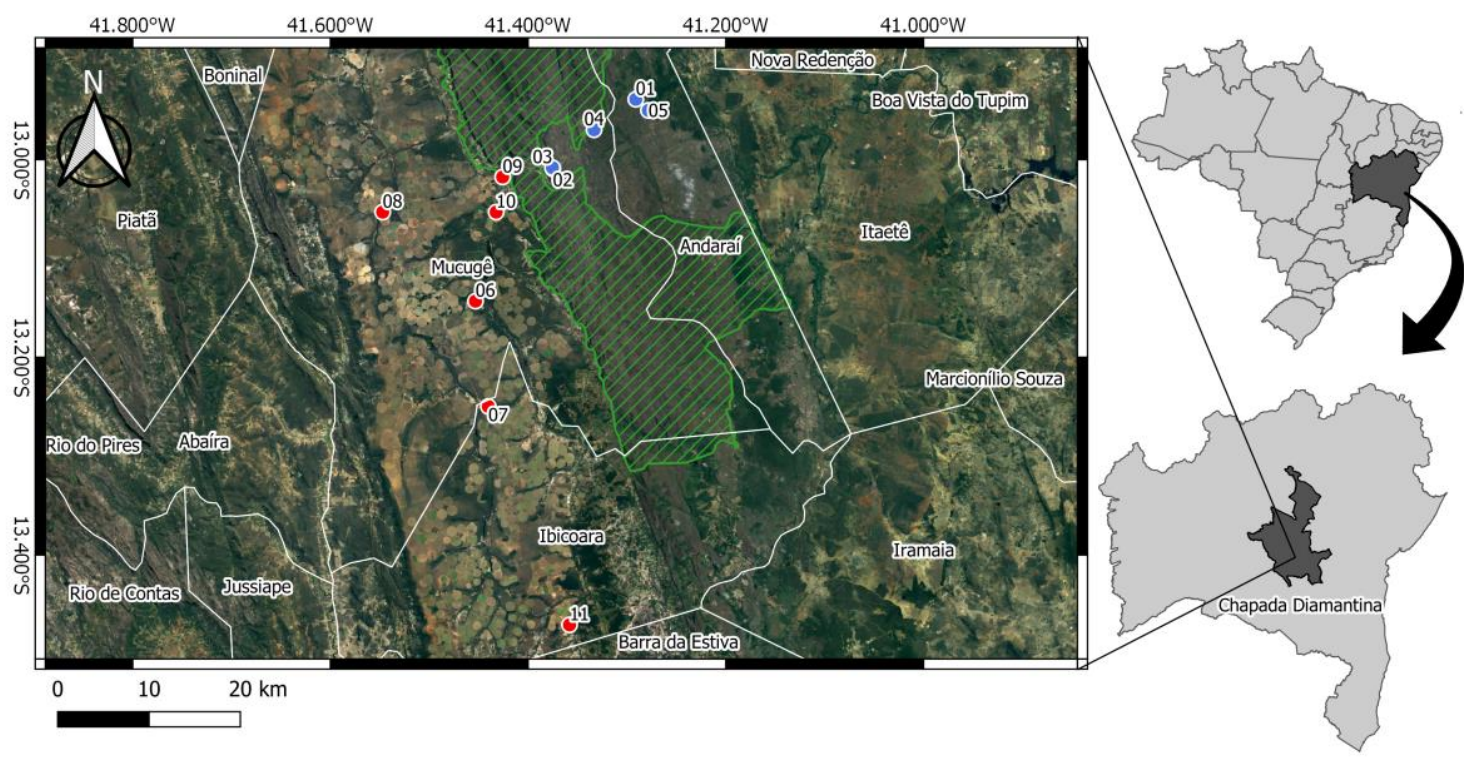

Subtitle

- Impacted area (Ibicoara-Mucugê Agro-pole)

- non-impacted area (Preserved area)

Projected coordinate system

Datum WGS84

Z Chapada Diamantina National Park

Fonte: SEI BA; IBGE; Landsat.

Figure 1: Localization of the sampling sites in the Chapada Diamantina - Bahia State, Brazil. Sampling points 1-5 in preserved areas within and/or around the Chapada Diamantina National Park, sampling points 6-11 in areas impacted by agrochemicals in agricultural areas within the Ibicoara-Mucugê Agropole. The Paraguaçu river is highlighted.

Farms' plantations werecoffee (reservoir and two streams - sites 06, 07 and 11 respectively), corn (stream - site 08), vegetables (puddle- site 09), and pumpkin (swamp - site 10); the tadpoles were collected near dams $(\mathrm{n}=1)$, streams $(\mathrm{n}=3)$, pools and swamps $(\mathrm{n}=3)$. Farms are located in the municipalities of Ibicoara and Mucugê in a densely agricultural region known as the IbicoaraMucugê Agro-pole. During the fieldwork, we observed severe environmental degradation resulted from vegetation suppression and pesticide use linked to the agricultural activities.

The samples at the non-impacted areas were taken in from the aquatic environments within the borders of the well-protected Chapada Diamantina National Park, in the municipalities of Mucugê and Palmeiras, including streams $(\mathrm{n}=2)$ and rocky pools $(\mathrm{n}=3)$. They were swamps (sites 01 and 04), streams (02 and 03), and puddles between rocks of the Piaba river (site 05).

The tadpoles of 11 frog species were collected using nets and held while in the field in $5 \mathrm{~L}$ plastic sacks containing water from their respective collection sites. The specimens were subsequently transported to the Zoology Laboratory at the Federal University of Bahia, Campi Anisio Teixeira, in the municipality of Vitória da Conquista, for the analysis. A total of 154 tadpoles were analyzed, being 73 from the environmentally preserved sites (Chapada Diamantina National Park) and 81 from sites impacted by agrochemicals (agricultural areas).

The tadpoles collected demonstrated development stages 26 through 43, following Gosner (1960) [30]. In the preserved areas, we analyzed the tadpoles of: Bokermannohyla oxente, stages 26-41 (point 4, $\mathrm{n}=12$ tadpoles), Leptodactylus latrans, stages 28-30 (point 3, $\mathrm{n}=12$ ); Leptodactylus mystacinus, stages 39-41 (point 1, $\mathrm{n}=21$ ); Leptodactylus vastus, stages 36-43 (point $1, \mathrm{n}=4$ ); Physalaemus cuvieri, stages 26-36 (points 2 and 3, $\mathrm{n}=11$ ); and Rupirana cardosoi, stages $34-40$ (point $5, \mathrm{n}=13$ ).

In the farming areas, we analyzed the tadpoles of: Bokermannohyla sp. stages $26-31$ (point 7, $\mathrm{n}$ $=30$ ); B. oxente, stages 26-41 (point 11, $\mathrm{n}=07$ ); Boana albopunctata, stages 30-36 (point $6, \mathrm{n}=$ 15); L. latrans, stages $30-40$ (point $8, \mathrm{n}=17$ ); Odontophrynus carvalhoi, stages $26-36$ (point $6, \mathrm{n}$ =4); Scinax x-signatus, stages 26-36 (point 9, $\mathrm{n}=4$ ); and Scinax montivagus, stages 26-39 (point $9, \mathrm{n}=4)$. 
Immediately after arriving in the laboratory, we acclimatized the captured animals for six hours in aquariums containing water from their respective collectionsites. The tadpoles were then anesthetized with $2 \%$ lidocaine chlorite gel and blood samples collected by cardiac puncture. A 10 $\mu \mathrm{L}$ aliquot of each blood sample was deposited in a micro-tube containing $500 \mu \mathrm{l}$ of physiological solution and $10 \mu \mathrm{l}$ of EDTA. Blood smears were then prepared (two slides per tadpole) and fixed with methanol for $10 \mathrm{~min}$., dried at room temperature, and finally stained with $6 \%$ May GrunwaldGiemsa in Sorensen buffer (pH 6.8) for 20 min [31].

Micronucleus frequencies were determined by examining 1000 erythrocytes on each slide for each tadpole, using an oil immersion light microscope (at 1000X magnification) [31]. The coded and randomized slides were evaluated by a single observer. The criteria adopted for determining the presence of micronuclei follow Silva et al. (2020) [31] being: non-refractory particles with shapes, colors, and intensities similar to the principal nucleus, although not connected to it; their sizes would be smaller, up to one third of the size of the principal nucleus.

We determined the basal frequencies of micronucleated cells for each species as the mean number and standard deviation of erythrocytes that demonstrated that anomaly, expressed in per 1000 cells (\%). The Kruskal Wallis test was used to determine whether there were statistically significant differences between the micronucleus frequencies recorded at the different sampling points. The Dunnet's test was used to examine the main significant effects even further. The data of micronucleus frequencies observed in the two species occurring in both types of environments (impacted by agrochemicals and preserved) were analyzed using the Mann Whitney test; $p \leq 0.05$ was considered indicative of statistical significance. All the statistical tests were performed using Graph Pad Prism 5.00 software (GraphPad Software Inc., San Diego, CA, EUA).

\section{RESULTS AND DISCUSSION}

A single micronucleus was predominant in the erythrocytes analyzed. Other erythrocytes, however, demonstrated nuclear abnormalities, such as having a lobed nucleus or being bi-nucleated (arrowheads in Figures 2a and $2 \mathrm{~b}$ respectively). Those abnormalities were considered in our analysis as they are related to errors of cell division, processes of cellular death, as well as genotoxicity and/or mutagenicity [17] and have origins similar to micronuclei [32] as they occur at greater frequencies in situations of dramatic alterations in diet, pathology, or metabolic stress [33].

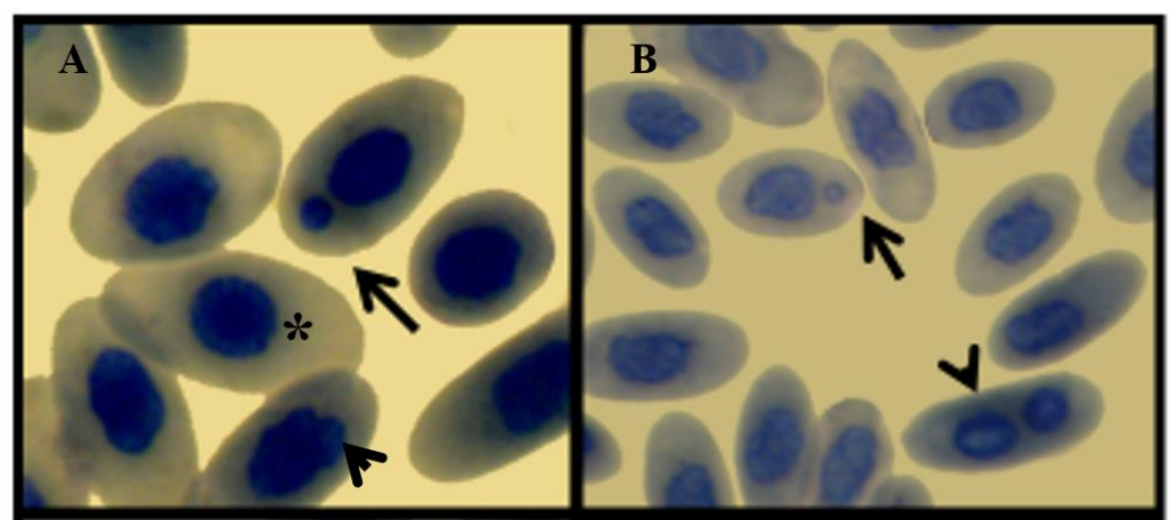

Figure 2: Nuclear alterations of erythrocytes in tadpoles collected from agricultural areas within the Ibicoara-Mucugê Agro-pole, Chapada Diamantina - Bahia State, Brazil. Blood smears stained using the Giemsa method, at 1000X magnification. A: Micronucleated erythrocytes (arrow), a normal nucleus (*) and a nucleus with lobes (arrowhead). B: Binucleated erythrocyte (arrowhead) and a micronucleus (arrow).

The frequencies of micronucleated erythrocytes were greater in tadpoles collected in impacted areas than in preserved sites (Table 01) (Figure 3) $(\mathrm{U}=1561, \mathrm{p}<0,0001)$. Several studies have indicated that the runoff of agricultural contaminants into aquatic environments can directly affect 
the survival, growth, and developmental rates of tadpoles, compromising their health, increasing their vulnerability to opportunistic parasites, and increasing the frequencies of nuclear erythrocytes aberrations or cell hemolysis [4, 6, 9, 10, 24, 26], thus altering community structures [34].

Table 1: Basal frequencies (mean \pm standard deviation) of micronucleated erythrocytes (per 1000 cells) observed in tadpoles in agricultural areas in the Ibicoara - Mucugê Agro-pole and in preserved environments in the Chapada Diamantina National Park - Bahia State, Brazil.

\begin{tabular}{lcc}
\hline \multicolumn{1}{c}{ Species } & Preserved environments & Agricultural areas \\
\hline Hylidae & - & $2.40 \pm 1.81$ \\
Bokermannohyla sp. & $1.25 \pm 1.48$ & $2.75 \pm 0.96$ \\
B. oxente & - & $2.33 \pm 1.99$ \\
Boana albopunctata & - & $0.75 \pm 1.50$ \\
Scinax montivagus & - & $1.00 \pm 1.00$ \\
S. - -signatus & $0.42 \pm 0.67$ & $1.47 \pm 1.12$ \\
Leptodactylidae & $1.43 \pm 1.08$ & \\
Leptodactylus latrans & $0.33 \pm 0.58$ & \\
L. mystacinus & $0.36 \pm 0.67$ & \\
L. vastus & $0.69 \pm 0.63$ & \\
Physalaemus cf. curvieri & & $3.75 \pm 0.87$ \\
Rupirana cardosoi & - & $2.18 \pm 1.79$ \\
Odontophrynidae & $1.01 \pm 1.09$ & \\
Odontophrynus carvalhoi & Total &
\end{tabular}

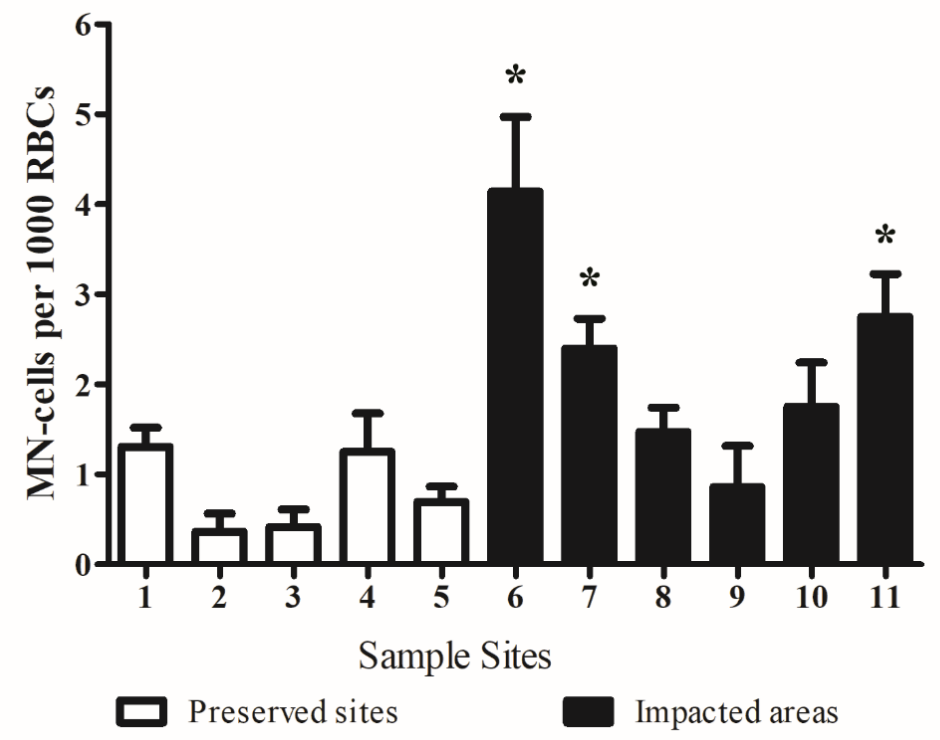

Figure 3: Mean micronucleus frequencies in tadpoles per collection site (points 1 to 11) in the IbicoaraMucugê Agro-pole and the Chapada Diamantina National Park, Bahia State, Brazil .* Indicates significant differences $(p<0.05)$.

Among the sites analyzed, impacted environments 06, 07 and 11 (coffee plantations) exhibited the highest micronucleus frequencies observed in the present study (Figure 3), statistically significant $(K=43.96 ; \mathrm{p}<0.001)$. Those plantations have taller and denser vegetations than the other cultures (corn, vegetables, and squash), and therefore likely used greater quantities of agro- 
defensive chemicals. Carneiro et al. (2012) [35] reported that just a single hectare of coffee plants is treated with an average of $10 \mathrm{~L}$ of pesticides (herbicides, insecticides, fungicides). It is also important to note that surface water bodies serve as collection basins for complex chemical mixtures of diverse origins, including a variety of toxic products from industrial effluents and urban residences [13].

Preserved environments 02 and 03 , on the other hand, demonstrated the lowest frequencies of tadpole erythrocyte micronuclei as compared to the impacted sites, except point 09 (Figure 3). The basal micronucleus frequencies seen in preserved areas between the towns of Mucugê and Palmeiras may reflect spontaneous events [13] and are therefore treated as comparative references for other populations of the same species present in agroecosystems.

Although we have not measured the concentration of pesticides in aquatic bodies, we collect tadpoles in places where we have identified the use of pesticides, such as the identification of inadequately disposed containers in the areas or the identification of the application in loco. Our study does not aim to classify pesticides and / or define they are responsible for genetic changes, but to highlight the stress caused by agricultural activities associated with the use of complex mixtures of pesticides, such as those we observed, including herbicides, insecticides, and fungicides. Thus, different from experimental studies, this work verifies the genomic damage in animals exposed in their natural habitat, under real conditions of contamination. However, further studies are in need to give further support of our findings as well as the isolation and characterization the pesticides that may be present in the surface water bodies.

Among the species analyzed, the tadpoles of Odontophrynus carvalhoi demonstrated the highest micronucleus frequencies. There were statistically significant differences in micronuclei frequencies between populations of L. latrans $(\mathrm{U}=45.50 ; \mathrm{p}=0.0088)$ and B. oxente $(\mathrm{U}=8.000$; $\mathrm{p}=0.0497$ ) occurring in impacted vs. preserved areas. That observation reinforces the apparent genotoxic (clastogenic) impacts of agricultural activities on anuran species, as they can induce, or increase genetic damage in tadpoles, decreasing the adaptive potentials of those species through the elimination of tadpoles with genotypes susceptible to chemical impacts [36, 37].

Ecotoxicological studies involving these neotropical species are scarce. Tadpoles of Odontophrynus carvalhoi exposed to concentrations of the commercial formula of the organophosphate chlorpyrifos (Klorpan ${ }^{\circledR}$ ) showed significant genetic changes in erythrocytes [31], immunosuppression in leukocytes [38], in addition to decreased survival and tail changes, making tadpoles slower and, therefore, perhaps more susceptible to predation and/or less efficient in foraging [39]. Such findings show the sensitivity of this specie to agrochemicals.

The anuran species analyzed in this work showed the presence of mutagenic agents in aquatic bodies from agricultural farms sampled in the Ibicoara-Mucugê agropole when comparing the specimens present in the preserved area of the Chapada Diamantina National Park. Similar results were found by Gonçalves et al. (2017) [40], for the species of Physalaemus curvieri, where populations living in agricultural areas (soybeans and corn) exhibited higher frequencies of DNA damage than those belonging to non-agricultural areas in the state of Goiás, Brazil. In this way, we can consider that anuran amphibians are excellent sentinels in environmental monitoring processes, showing previously impacts of xenobiotics to biota.

Odontophrynus carvalhoi, B. oxente, B. albopunctata, and $L$. latrans exhibited the greatest frequencies of micronucleated cells in the impacted environments. The variability of micronucleus frequencies observed in the different species investigated here could be related to differences in their metabolic competence and mechanisms of DNA repair. Those frequencies, however, were greater than those reported: by Gonçalves et al. (2012) [27] for adult individuals of Proceratophrys goyana, Dendropsophus soaresi, and Leptodactylus leptodactyloides near nickel mines in the region around Niquelândia-Barro Alto, Goiás State; by Babini et al. (2015) [24] for Rhinella arenarum in agroecosystems in Córdoba, Argentina; and by Pollo et al. (2016) [26] for tadpole and adult specimens of Hypsiboas cordobae near fluoride mines in Cerros Negros, Córdoba, Argentina. Those differences could be related to the greater sensibility of larval stage anurans, as they continually inhabit aquatic environments exposed to xenobiotics, thus being even more consistently exposed to aquatic contaminants than adults [26], in addition to interspecific differences in terms of their sensibilities to contaminants. 


\section{CONCLUSION}

In synthesis, the results of in vivo micronucleus tests indicated that chemical compounds present in the surface waters of agricultural areas surveyed in the Chapada Diamantina contain genotoxic substances that constitute potential dangers to local animal populations, especially anuran amphibians, and therefore cause significant damage to the environment and human health. Additionally, we were able to demonstrate that the neotropical anuran species $O$. carvalhoi, $B$. oxente, B. albopunctata, and L. latrans are competent sentinels for evaluating contamination in surface water bodies.

\section{ACKNOWLEDGEMENTS}

The authors thank the Ministério do Meio Ambiente do Brasil for the (Licença ICMBio $\mathrm{N}^{\circ}$ 27305-1) and the Comitê de Ética no Uso de Animais da Universidade (CEUA-UEFS, protocolo $\mathrm{N}^{\circ}$ 02/2012) for the licenses permitting this research project; the anonymous reviewers for their useful comments and suggestions; the Conselho Nacional de Desenvolvimento Científico e Tecnológico - CNPq: Edital MCT/CNPq No 59/2009 Programa de Pesquisas Ecológicas de Longa Duração PELD: Chapada Diamantina, and the Fundação de Amparo à Pesquisa do Estado de São Paulo - FAPESP: Projeto SISBIOTA: Girinos de Anuros da Mata Atlântica, da Amazônia, do Pantanal, do Cerrado e de Zonas de Transição: Caracterização Morfológica, Distribuição Espacial e Padrões de Diversidade (FAPESP proc. 2010/52321-7 e CNPq proc. 563075/2010-4) for funding the study.

\section{REFERENCES}

1. Verdade VK, Valdujo PH, Carnaval AC, Schiesari L, Toledo LF, Mott T, Andrade GV, Eterovick PC, Menini M, Pimenta BVS, Nogueira C, Lisboa CS, Paula CD, Silvano DL. A leap further: the Brazilian Amphibian Conservation Action Plan. Alytes. 2012;29(1-4):27-42.

2. Schiesari L, Grillitsch B. Pesticides meet megadiversity in the expansion of biofuel crops. Front Ecol Environ. 2010;9(4):215-221, doi: 10.1890/090139.

3. Moreira RA, Freitas JS,Silva-Pinto TJ, Schiesari L, Daam MA, Montagner CC, Goulart BV, Espindola ELG. Mortality, spatial avoidance and swimming behavior of bullfrog tadpoles (Lithobates catesbeianus) exposed to the herbicide diuron. Water, Air Soil Poll. 2019;230:125. doi: 10.1007/s11270-019-4168-z.

4. Mann RM, Hyne RV, Choung CB, Wilson SP. Amphibians and agricultural chemicals: Review of the risks in a complex environment. Environ Pollut. 2009;157(11):2903-2927, doi: 10.1016/j.envpol.2009.05.015.

5. Hayes TB, Falso P, Gallipeau S, Stice M. The cause of global amphibian declines: a developmental endocrinologist's Perspective. J Exp Biol. 2010;213(6):921-933, doi: 10.1242/jeb.040865.

6. Lajmanovich RC, Peltzer PM, Attademo AM, Cabagna-Zenklusen MC, Junges CM. Los agroquímicos y su impacto en los anfibios: un dilema de difícil solución. Quim Viva. 2012;3(11):184-198.

7. Houlahan J, Findlay CS. The effects of adjacent land use on wetland amphibian species richness and community composition. Can J Fish Aquat Sci. 2003;60(9):1078-1094, doi:10.1139/f03-095.

8. Davidson, C. Declining downwind: amphibian population declines in California and historical pesticide use. Ecol Appl. 2004;14:1892-1902, doi: 10.1890/03-5224.

9. Peltzer PM, Lajmanovich RC, Sánchez-Hernandez JC, Cabagna MC, Attademo AM, Bassó A. Effects of agricultural pond eutrophication on survival and health status of Scinax nasicus tadpoles. Ecotoxicol Environ Saf. 2008;70(1):185-197, doi: 10.1016/j.ecoenv.2007.06.005.

10. Gonçalves MW, Campos CBM, Godoy, FR, Gambale PG, Nunes, HF, Nomura F, Bastos RP, Cruz AD, Silva, DM. Assessing genotoxicity and mutagenicity of three common amphibian species inhabiting agroecosystem environment. Arch Environ Contam Toxicol. 2019;77:409-420, doi: 10.1007/s00244-01900647-4.

11. Arcaute CR, Pérez-Iglesias JM, Nikoloff N, Natale GS, Soloneski S, Larramendy ML. Genotoxicity evaluation of the insecticide imidacloprid on circulating blood cells of Montevideo tree frog Hypsiboas pulchellus tadpoles (Anura, Hylidae) by comet and micronucleus bioassays. Ecol Ind. 2014;45:632-639, doi: 10.1016/j.ecolind.2014.05.034. 
12. Bosch B, Mañas F, Gorla N, Aiassa D. Micronucleus test in post metamorphic Odontophrynus cordobae and Rhinella arenarum (Amphibia: Anura) for environmental monitoring. J Toxicol Environ Health Sci. 2011;3:155-163.

13. Ossana NA, Salibián A. Micronucleus test for monitoring the genotoxic potential of the surface water of Luján River (Argentina) using erythrocytes of Lithobates catesbeianus tadpoles. Ecotoxicol Environ Contam. 2013;8(1):67-74, doi: 10.5132/eec.2013.01.010.

14. Bolognesi C, Hayashi M. Micronucleus assay in aquatic animals. Mutagenesis. 2011;26(1):205-213, doi: 10.1093/mutage/geq073.

15. Al-Sabti K, Metcalfe CD. Fish micronuclei for assessing genotoxicity in water. Mutat Res-Gen Toxicol En. 1995;343(2-3):121-135, doi: 10.1016/0165-1218(95)90078 -0.

16. Wirz MVMA, Saldiva PH, Freire-Maia DV. Micronucleus test for monitoring genotoxicity of polluted river water in Rana catesbeiana tadpoles. Bull Environ Contam Toxicol. 2005;75(6):1220-1227, doi: 10.1007/s00128-005-0879-5.

17. Ossana NA, Castañé PM, Poletta GL, Mudry MD, Salibián A. Toxicity of waterborne copper in premetamorphic tadpoles of Lithobates catesbeianus (Shaw, 1802). Bull Environ Contam Toxicol. 2010;84:712-715, doi: 10.1007/s00128-010-0014-0.

18. Ghisi NC, Oliveira EC, Fávaro LF, Silva de Assis HC, Prioli AJ. In situ assessment of a neotropical fish to evaluate pollution in a river receiving agricultural and urban wastewater. Bull Environ Contam Toxicol. 2014;93(6):699-709, doi: 10.1007/s00128-014-1403-6.

19. Wachtel CC, Oliveira EC, Maniglia TC, Smith-Johannsen A, Roque AA, Ghisi NC. Waterborn genotoxicity in southern Brazil using Astyanax bifasciatus (Pisces: Teleostei). Bull Environ Contam Toxicol. 2019;102(1):59-65, doi: 10.1007/s00128-018-2477-3.

20. Cardoso RL, Carvalho-Neta RNF, Castro ACL, Ferreira CFC, Silva MHL, Azevedo JWJ, Costa JRS Sobrinho, Santos DMS. Histological and genotoxic biomarkers in Prochilodus lacustris (Pisces, Prochilodontidae) for environmental assessment in a protected area in the northeast of Brazil. Bull Environ Contam Toxicol. 2018;101(2018):570-579, doi: 10.1007/s00128-018-2464-8.

21. Sousa EL, Pereira NJ, Gomes JB, Santos MM, Santos DMS. Ecotoxicological analyses of springs of a Brazilian Northeast Conservation Unit. Bull Environ Contam Toxicol. 2020;104:27-34, doi: 10.1007/s00128-019-02757-0.

22. Lajmanovich RC, Peltzer PM, Attademo AM, Cabagna-Zenklusen MC, Junges CM. Micronucleus induction in erythrocytes of the Hyla pulchella tadpoles (Amphibia: Hylidae) exposed to insecticide endosulfan. Mutat Res-Gen Toxicol. 2005;587(1-2):67-72, doi: 10.1016/j.mrgentox.2005.08.001.

23. Peltzer PM, Lajmanovich RC, Attademo AM, Junges CM, Cabagna-Zenklusen MC, Repetti MR, SigristcBeldoménico $\mathrm{H}$. Effect of exposure to contaminated pond sediments on survival, development, and enzyme and blood biomarkers inveined tree frog (Trachycephalus typhonius) tadpoles. Ecotoxicol Environ Saf. 2013;98:142-151, doi: 10.1016/j.ecoenv.2013.09.010.

24. Babini MS, Bionda CL, Salas NE, Martino AL. Health status of tadpoles and metamorphs of Rhinella arenarum (Anura, Bufonidae) that inhabit agroecosystems and its implications for land use. Ecotoxicol Environ Saf. 2015;118:118-125, doi: 10.1016/j.ecoenv.2015.04.017.

25. Josende ME, Tozetti AM, Alalan MT, Mathies V Filho, Ximenez SS, Da Silva FMR Júnior, Martins SE. Genotoxic evaluation in two amphibian species from Brazilian subtropical wetlands. Ecol Ind. 2015 Feb;49(2014):83-87, doi: 10.1016/j.ecolind.2014.10.007.

26. Pollo FE, Grenat PR, Otero MA, Salas NE, Martino AL. Assessment in situ of genotoxicity in tadpoles and adults of frog Hypsiboas cordobae (Barrio 1965) inhabiting aquatic ecosystems associated to fluorite mine. Ecotoxicol Environ Saf. 2016;133:466-474, doi: 10.1016/j.ecoenv.2016.08.003.

27. Gonçalves MW, Oliveira HHP, Carvalho WF, Silva DM, Nomura F, Bastos RP, Da Cruz AD. Análises mutagênicas de anuros em áreas de mineração de níquel. Estudos. 2012;339(2):115-121, doi: 10.18224/est.v39i2.2592.

28. Juncá FA, Funch L, Rocha W. Biodiversidade e conservação da Chapada Diamantina. Brasília (DF): Ministério do Meio Ambiente; 2005. 411 p.

29. Silva MB. Biomarcadores ecotoxicológicos em girinos como subsídios para monitoramento ambiental. [PhD thesis]. Salvador (BA): Universidade Federal da Bahia; 2014. 83 p.

30. Gosner KL. A simplified table for staging anuran embryos and larvae with notes on identification. Herpetologica. 1960;16:183-190.

31. Silva MB, Fraga RE, Nishiyama PB, Costa NLB, Silva ISS, Queiroz TS, Rocha MA, Juncá FA. Genotoxic effect of the insecticide Chlorpyrifos on the erythrocytes of Odontophrynus carvalhoi tadpoles (Amphibia: Odontophrynidae). Ecotoxicol Environ. Contam. 2020;15(1):9-13, doi:10.5132/eec.2020.01.02.

32. Serrano-García L, Montero-Montoya R. Micronuclei and chromatid buds are the results of related genotoxic events. Environ Mol Mutagen. 2001;38:38-45, doi:10.1002/em.1048. 
33. Barni S, Boncompagni E, Grosso A, Bertone V, Freitas I, Fasola M, Fenoglio C. Evaluation of Rana snk esculenta blood cell response to chemical stressors in the environment during the larval and adult phases. Aquat Toxicol. 2007;81(1):45-54, doi:10.1016/j.aquatox.2006.10.012.

34. Relyea RA, Schoeppner NM, Hoverman JT. Pesticides and amphibians: the importance of community context. Ecol Appl. 2005;15(4):1125-1134, doi:10.1890/04-0559.

35. Carneiro FF, Pignati, W, Rigotto RM, Augusto LGS, Rizzolo A, Faria NMX, Alexandre VP, Friedrich K, Mello MSC. Dossiê ABRASCO - Um alerta sobre os impactos dos agrotóxicos na saúde. Parte 1 Agrotóxicos, Segurança Alimentar e Nutricional e Saúde. Rio de Janeiro (RJ): ABRASCO; 2012 [cited 2020 Out 19]. 88 p. Available from: https://www.abrasco.org.br/site/wpcontent/uploads/2015/03/Dossie_Abrasco_01.pdf

36. Grisolia CK. Agrotóxicos: mutações, câncer e reprodução. Brasília (DF): Editora da UNB; 2005.392 p.

37. Udroiu I. The micronucleus test in piscine erythrocytes. Aquat Toxicol. 2006;79(2):201-204, doi:10.1016/j.aquatox.2006.06.013.

38. Silva MB, Fraga RE, Nishiyama PB, Silva ISS, Costa NLB, Oliveira LAA, Rocha MA, Juncá FA. Leukocyte profiles in Odontophrynus carvalhoi (Amphibia: Odontophrynidae) tadpoles exposed to organophosphate chlorpyrifos pesticides. Water Air Soil Pollut. 231:372, doi: 10.1007/s11270-02004726-4.

39. Silva MB, Fraga RE, Silva FL, Oliveira LAA, Queiroz TS, Rocha MA, Juncá FA. Effects of acute exposure of chlorpyrifos on the survival, morphology and swimming ability of Odontophrynus carvalhoi tadpoles. Ecotoxicol Environ Contam. 2020;15(1):37-42, doi: 10.5132/eec.2020.01.05.

40. Gonçalves MW, Gambale PG, Godoy FR, Alves AA, Rezende PHA, da Cruz AD, Maciel NM, Nomura F, Bastos RP, de Marco-Jr P, Silva DM. The agricultural impact of pesticides on Physalaemus cuvieri tadpoles (Amphibia: Anura) ascertained by comet assay. Zool. 2017;34:e19865, doi:10.3897/zoologia.34.e198 